DOI: 10.2478/rae-2021-0005 Review of Artistic Education no. $212021 \quad 31-34$

\title{
5. HISTORICAL AND THEORETICAL FOUNDATIONS OF THE DEVELOPMENT OF VOCAL AND CHORAL CULTURE IN MOLDOVA
}

Ana Glebov ${ }^{12}$

\begin{abstract}
The origins of the national choral art are based on Church singing, which has been widely developed since the founding of the Putnyansky and Nyametsky monasteries. In the further development of the centuries, Church singing intertwined with folk choral singing, which was reflected in the works of such conductors and composers as G. Muzichesku, M. Berezovsky, A. Kristya, M. Byrke, V. Popovich. Special attention is paid to the creative and conducting activities of Gavriil Muzichesku, all of whose initiatives were innovative and progressive, later becoming the leading ones in the national choral activities of Romania and Moldova. This article identifies and systematizes the main trends related to the process of creating vocal and choral works and their application in the system of Romanian and Moldovan musical education. Their analysis shows that the composer worked on the theoretical generalization of his own experience, turned to the best ideas of domestic and foreign pedagogy, including Russian, and thanks to this he was able to bring his knowledge and experience into a fairly coherent and integral system of musical education and education through vocal and choral culture.
\end{abstract}

Key words: vocal and choral culture, vocal creativity, Church singing, musical education, pedagogy

\section{Introduction}

The development of social and socio-cultural processes at the present stage is, characterized by an increased interest in the deep origins of Russian culture. A positive trend in this direction was the revival of the historical and cultural traditions of Moldova, and in particular the traditional vocal and choral culture, which contains a rich pedagogical potential, including performing, composing and educational traditions. However, despite the widespread development of vocal and choral performance, regional traditions of the choral genre are almost not used. In the practical activities of various educational and cultural institutions, there is also an underestimation of the importance of local vocal traditions of the region, which leads to significant shortcomings in the aesthetic education of the younger generation. So, having analyzed the training programs of conducting and choral departments of various music and pedagogical faculties (on choral studies, methods of working with the choir, history of choral creativity, music pedagogy and psychology, history of national music, theory and history of folk art culture) we did not find a regional component of the content of education, and in particular the reliance on local singing traditions.

\section{Discussions}

In contrast to innovative trends, there are also negative factors. In particular, the upbringing and education of the younger generation is poorly, focused not only on performing activities, but also on the perception of vocal and choral art. Despite the fact that the younger generation is actively in contact with the vocal and choral

\footnotetext{
${ }^{12}$ Assistante Candidate Doctoral / „Alecu Russo” State University from Bălţi, Republic of Moldavia, email: annag11982@mail.ru
} 
culture of the region, numerous sociological studies have shown that modern youth are mainly interested in samples of Western musical creativity. At the same time, there is a significant interest in the cultural traditions of the region and especially folklore. This is reflecting in the growing number of participants in folk ensembles. The problems of music and choral education, performance and education are most fully, developed in the studies of choral figures. So, questions of the history of choral performance were touched upon by Sh. Andronik, E. Mamot, V. Kryanga, Sh. Karanfil, E. Maryan, A. Prisekaru, S. Istrati, M. Gania, V. Budilevsky, E. Bogdanovsky, I. Popescu (Kishinev); M. Sokolan (Tiraspol).

With the foundation of the Moldavian state, musical education was subordinated to the church position and had a religious character. Historian C. Andreescu writes: „In the first years of our state life, the school was inextricably linked with the church. Episcopates, monasteries, churches have always been schools where children learned to write, read and sing" [1, p. 3]. Episcopal, monastic, and ecclesiastical schools aimed not so much at teaching children to read, write, and develop their intellectual abilities, but at the religious and moral education of obedient believers and church servants. In its efforts to assert itself, the church introduces church music and literature into school programs. It should, be pointed out that there is very little direct information about the existence of schools in the monasteries of Moldova of the XV-XVII centuries. But there is a lot of indirect evidence, which undoubtedly shows that under the majority of Moldavian monasteries there were almost continuously, for a very long period, certain centers for teaching children and youth, which in the scientific literature are usually called ,,monastic schools” [7, p. 11-12]. Church educators played an important role in the creation of these schools from neighboring Slavic countries. When they came to Moldova, they brought with them various handwritten books, mostly of religious content, which used were to teach the local population. Founded by enlighteners, schools attached to monasteries, monasteries and churches become centers of writing and culture [6, p. 3-5].

Therefore, there was the most ancient monasteries of Moldova: Neamt, Bistrita, Moldovița, Agapia, Putna, etc. The most significant were the schools attached to the Nyamec and Putna monasteries, which in the Middle Ages became the leading centers of musical education and education in Moldova. "NovoNyamets Holy Ascension Monastery in the village of Kitskany is a unique monument of history and culture of Moldova in the second half of the XIX-XX centuries. The significance of this monastery for the culture of our region is difficult to overestimate. After all, with its history, many events in Bessarabia of the second half of the XIX century" [10].

„In the Moldavian Principality, music was also practiced professionally; for example, around 1500, a singing school was established in the Putnyansky Monastery" [11]. Training in singing schools was not limited to the act of simple apprenticeship, but was systematized and based on proven methods and principles, this is confirmed by researchers G. Ciobanu [4], I. Barbulescu [2]. At the same time, special textbooks on church music initially brought from Byzantium, Bulgaria and Serbia. Thus, already in the XVI century in Moldova there was a certain system of school musical education, which was, determined by the didactic 
content, goals, principles and methods of musical education, used textbooks on music and was, carried out by preparatory teachers. By the beginning of the XVII century, in Moldova, along with church and monastery schools, a number of schools established by the power of the lord appeared. These are the school in Hurlau (1558), in Kotnari (1563), the Iasi Collegium (1640), which marked the beginning of the development of secular education in Moldova.

\section{Results}

Numerous documents and archival materials show that in the curricula of these schools there is a subject ,church singing” [5, p.161], the purpose of which is not only to educate the main aspects of spiritual, moral, artistic and aesthetic culture, but also to instill in students a vocal and choral culture. After Bessarabia became part of Russia, Russian and Western European musical culture began to penetrate the region. There were tours of foreign opera and operetta companies, vocalists and instrumentalists, including such celebrities as Franz Liszt and Robert Schumann. Concerts and theatrical and musical performances are being organized, theater and concert halls are being built, and music educational institutions are being opened.

Since the end of the XVIII century, Moldovan folk melodies have begun to attract Russian and Western European composers. One of the founders of Moldovan professional music was the composer and choirmaster G. V. Muzicescu. An important factor that influenced the development of the content of musical education and education was the development of choral music, as one result of which the authorities decided in 1874 to hold choral classes in state educational institutions [8]. In the beginning, as is usual in all church endeavors, they have a purely religious connotation. It was necessary for a long time for choirs to use secular materials for their activities. The brightest representative of this direction is Gabriel Muzicescu. He was one of the first to compose music for choirs, including school choirs, as well as to make, arrangements for the choir of folk songs and melodies. Thanks to the choral activity introduced into the content of school musical education, the didactic and educational goals of the subjects ,singing", which consist in the formation of pure intonation skills, are expanded. This follows from the program of the Chisinau Progymnasium (1878), ,...singing was made mandatory for all who have a voice, the consequence of which was the revival of the love of singing and the formation of a beautiful children's choir" [9].

The next representative of the choral culture of the interwar period of the historical development of Bessarabia was the composer and teacher Mihai Byrke, who made a significant contribution not only to the development of professional music education, but also to the development of general musical education in Bessarabia. Combining the activities of a teacher at the conservatory and a vocal music teacher at the 2nd Chisinau Men's Gymnasium, „M. Eminescu”, as well as a teacher of the choral class of the Lyceum No. 2 for boys in Chisinau, he made a significant contribution to the development of new directions in the content of musical education. Working on folk melodies, he arranged them for children's choirs, thereby enriching the school repertoire with beautiful works of folk art. M. Byrke also organized for the first time in Bassarabia a school musical theater, 
composing a children's opera for this purpose.

Another bright personality who left a deep mark on the development of choral culture in the interwar period of Bessarabia is the composer, conductor and teacher Mikhail Berezovsky. As a conductor of the church choir and the choir of the diocesan Cathedral, he undertakes serious research in the field of folklore and sacred music [3]. These studies are widely used in his teaching activities. He also works a lot on creating a school choral repertoire. Another representative of the choral direction of this period is Vasily Popovich, who developed his activities starting as a music teacher in schools in Tigina, and then in the lyceum and conservatory in Chisinau. V. Popovich made a great contribution to the development of musical education, creating a choir and orchestra at the lyceum, while using the best examples of folk music as a repertoire. The above material allowed us to state that in the interwar period (1918-1940) musical education, as well as vocal and choral culture of Bessarabia, received significant development. Church music education continues to develop through the opening of theological seminaries. New textbooks and books of church music are published (M. Berezovsky, N. Lungu, I. Kroitoru), in which choral scores were included.

\section{Conclusions}

Thanks to the opening of conservatories in Chisinau, professional musical education is further, developed, where choral singing occupies an important place, the choral repertoire is expanded and enriched, which contributes to raising the cultural level of this period. Many professors of conservatories combine their teaching activities with work in a comprehensive school, which makes a significant contribution to improving the level of school choral education. Assessing the musical and choral education of Bessarabia in the interwar period, it can be determined that it was, formed under the influence of the main progressive socio-pedagogical trends of that period, which consisted in the struggle for the creation of a national choral system of musical education and education.

\section{References}

1. Andreescu C. A. (1935) „Evoluția învăţămîntului în Moldova”. Ed. Bravo, Iași

2. Barbulescu I. (1925) „Academie de muzica bisericească”. Ed. Muzicală, Arhiva, București

3. Berezovschi M. (1936) „Carte de cîntece religioase”. Ed. Prut Internațional, Chișinău

4. Ciobanu Gh. (1966), ,Școala muzicală de la Putna”. [The Music School from Putna]. Ed. Muzica [,Music” Journal], № 9, pp. 14-20. București

5. Ciobanu Gh. (1938), „Școala muzicală din Cotnari”. Ed. Lumina, București

6. Grigoraș N., Caproșu I. (1971) „Biserici și manastiri vechi din Moldova”. Ed. Meridiane, Bicirești

7. Krachun T. A. (1969) ,Essays on the history of school development and pedagogical thought in Moldova", Lumina Publishing House, Chisinau

8. NARM: f. 316 , op. 1 , d. $832,1.3$

9. NARM: f. 152 , op. 1, d. $91,1.7$

\section{Online resources}

10. *** Materials of the site Russian Resurrection: the Orthodox monastery: NovoNyametsky Holy Ascension Monastery http://www.voskres.ru/obiteli/novoniam.htm; 11. *** Materials of the site ru.wikipedia.org > wiki > The Moldavian Principality 